\title{
Nutritional characteristics of ancient Tuscan varieties of Triticum aestivum $L$.
}

\author{
Lisetta Ghiselli, ${ }^{1}$ Eleonora Rossi, ${ }^{1}$ Anne Whittaker, ${ }^{1}$ Giovanni Dinelli, ${ }^{2}$ \\ Adriano Pasqualino Baglio, ${ }^{1}$ Luisa Andrenelli, ${ }^{1}$ Stefano Benedettelli ${ }^{1}$ \\ ${ }^{1}$ Department of Agrifood Production and Environmental Sciences, University of Florence, \\ Florence; ${ }^{2}$ Department of Agricultural Sciences, University of Bologna, Bologna, Italy
}

\begin{abstract}
Bread wheat (Triticum aestivum L.) is an important cereal in human consumption. In recent years, there has been a growing interest in ancient wheat varieties. The latter represent an important source of germplasm, characterised by a broader genetic base and, therefore, a potential source of biodiversity. The objective of the study was to ascertain the optimal balance between the presence of secondary metabolites having beneficial effects on health and technological features that ensure successful baking quality. The experimental trial was performed in 2011-2012 on three organic farms located in three different areas within the province of Siena (Tuscany). In each location, an overall evaluation of the commercial, rheological and functional properties of five ancient Tuscan bread wheat varieties (Andriolo, Frassineto, Gentil rosso, Inallettabile 96, Verna) as compared with a commercial modern variety (Palesio) was carried out. The ancient varieties were compared both singularly (pure) and in combination (mixtures) of two varieties in equal proportion, respectively. Biometric
\end{abstract}

Correspondence: Lisetta Ghiselli, Department of Agrifood Production and Environmental Sciences, University of Florence, Piazzale delle Cascine 18, 50144 Firenze, Italy.

E-mail: lisetta.ghiselli@unifi.it

Key words: Bread wheat; mixture; rheological properties; secondary metabolite; germplasm.

Acknowledgements: the research was financed by the Provincia di Siena and was supported by a grant from the Ente Cassa di Risparmio di Firenze, which contributed to the acquisition of a part of the instrumentation used for this work. Thanks are extended to Dr. Francesca Castioni and Andrea Battino for technical support in field trials and on the choice of farms. Special thanks go to Dr. Sigfrido Romagnoli for revising and correcting the text.

Conflict of interest: the authors declare no potential conflict of interest.

Conference presentation: SIA XLIV Congress, Bologna, 2015.

Received for publication: 22 January 2016.

Revision received: 30 May 2016.

Accepted for publication: 30 May 2016.

(C) Copyright L. Ghiselli et al., 2016

Licensee PAGEPress, Italy

Italian Journal of Agronomy 2016; 11:750

doi:10.4081/ija.2016.750

This article is distributed under the terms of the Creative Commons Attribution Noncommercial License (by-nc 4.0) which permits any noncommercial use, distribution, and reproduction in any medium, provided the original author(s) and source are credited. and productive parameters were detected for each plot (32 plots in each farm). Macro- and trace elements, polyphenols, flavonoids and antioxidant activity (antiradical power, ARP) were similarly determined on representative whole grain samples. Rheological analysis was carried out on flour samples. The multivariate statistical analysis using principal components analysis was performed on all variables analysed. The results showed a significant environment effect on the different parameters measured and did not reveal significant improvements in the variables measured when varieties were cultivated in mixtures. However, the study did reveal various interesting trends that are warranting of further investigation.

The most interesting effect from a nutritional and functional point of view is the relationship between ARP, rheological properties, protein content and gluten content. These connections permit the potential towards the improvement of ancient varieties.

\section{Introduction}

The re-discover of ancient wheat varieties as functional food (Dinelli et al., 2007; Di Silvestro et al., 2012; Leoncini et al., 2012) is the main reason for renewed interest in ancient grains. Ancient or old wheat varieties are comprised of local landraces (for example Gentil rosso), as well as those varieties obtained from the original landraces. All were well adapted to the environment before the introduction of high energy input agriculture. These varieties were the result of the activity of Italian geneticists operating from the early 1900 s, including Todaro (pure line selection), Strampelli (crossing and pedigree selection), Avanzi, Michahelles, Oliva and Gasparini (crossing inter-varieties). In Tuscany, many existing wheat varieties, registered before the 1980 s, were derived from the local breed Gentil rosso, using genealogical and mass selection techniques (Benedettelli et al., 2013). According to the definition of Bordes et al. (2008), modern wheat varieties are those registered after the 1960s. However, a legal instrument introduced under Tuscan regional law, LR 64/04, aims to protect and enhance the important patrimony of endangered varieties through the introduction of regional repositories of local Tuscan breeds and varieties. It is possible to include local varieties and breeds (species, varieties, cultivars, landraces, populations and clones originating in Tuscany), which are maintained by a network of growers-keepers. Currently, there are 17 Tuscan Triticum varieties (http://germoplasma.arsia.toscana.it).

Bread wheat (Triticum aestivum L.) is an important cereal for human consumption. Bread wheat is not only a valuable source of starch and protein, but is also rich in fiber, vitamins, minerals and secondary metabolites. The latter, known as functional or bioactive compounds, were largely overlooked in genetic improvement programs. These functional components with health benefits are comprised of polyphenols (flavonoids, lignans, isoflavones) and tocopherols, and are more abundant in wholegrain, encompassing all three fractions of the seed, namely the bran, germ, and endosperm. Short-term in vivo experiments, involving the consumption of bread (Sofi et al., 2010) 
and pasta (Ghiselli et al., 2013), using semi-integral wheat flour and semolina (0.9-1.2\% ash), showed an improvement in various parameters related to atherosclerotic risk. In recent years, particular attention has been paid to the polyphenol content, and related antioxidants, which have been shown to be qualitatively different between modern and ancient varieties of Triticum aestivum (Dinelli et al., 2007, 2011). This confirms that the ancient varieties are characterised by a broader genetic base and, therefore, represent a potential source of biodiversity. Some recent studies have shown the presence of interesting phytochemical profiles in some ancient varieties in comparison to modern varieties (Di Silvestro et al., 2012; Leoncini et al., 2012). Besides the cultivar, the climate (Stracke et al., 2009; Heimler et al., 2010; Gasztonyi et al., 2011), the environment (Mpofu et al., 2006; Lu et al., 2015 ) and the genotype $\times$ environment interactions (William et al., 2008; Okarter et al., 2010; Lv et al., 2013) also play important roles impacting heavily on the content of these substances.

The ancient varieties were all selected under organic farming. Hence, the comparison between organic and conventional (under which the modern varieties were selected) farming is a valid consideration. Conventional farming was shown to result in an improvement in the baking quality of bread wheat (Mazzoncini et al., 2015), even if this was at a cost to the functional qualities. However, the quantity of protein and gluten in the flour of ancient varieties is not always inferior to that of modern varieties (Ghiselli et al., 2010). The differences are related more specifically to quality (Van den Broeck et al., 2010). The rheological properties of dough made with the flour of modern varieties are more variable than that of the ancient varieties (Bordes et al., 2008). The $W$ value of flour, a parameter used to measure flour strength, is usually less than 150 in ancient varieties, therefore low in comparison to standard grade wheat, where $\mathrm{W}$ exceeds 170 . Hence, when evaluating ancient varieties, it is important to establish the genetic potential based on the best compromise between functional and technological properties.

Cultivar mixtures are increasingly being used in commercial agriculture to control diseases, increase yield, and provide yield stability (Garrett and Mundt, 1999; Finckh et al., 2000; Mundt, 2002). Using four winter wheat varieties, Swanston et al. (2005) observed that there was a greater variation in productive characteristics among individual varieties than when the varieties were cultivated in mixtures. However, to our knowledge no work has been published on functional characteristics and rheological properties in varieties cultivated in mixtures.

Therefore, the aim of this study was to perform an overall evaluation of the nutritional, nutraceutical and rheological properties of various ancient varieties in the Tuscan germplasm collection as compared with a commercial modern variety. The ancient varieties were cultivated either singularly or in combination with other ancient varieties under organic farming conditions. The objective was to ascertain the optimal balance between the presence of secondary metabolites having beneficial effects on health and the technological features that ensure successful baking quality.

\section{Materials and methods}

The experimental trial was performed in 2011-2012 on three organic farms located in three different areas within the province of Siena (Tuscany). The farms were: Farm 1) Società Agricola F.lli Guasconi Villamena s.s. (San Rocco a Pilli, Sovicille, Siena, Italy; $43^{\circ} 14^{\prime} 48^{\prime \prime}$ N, $11^{\circ} 17^{\prime}$ 43" E, 241 m a.s.l.); Farm 2) Società Agricola Voltolini Stefano and Simonetti Enrico s.s. (Torrita di Siena, Siena, Italy; $43^{\circ} 10^{\prime} 8$ " N, $11^{\circ} 46^{\prime} 29 "$ E, $430 \mathrm{~m}$ a.s.l.) and Farm 3) Grappi Luchino Farm (Monticchiello, Pienza, Siena, Italy; 43 3' 55” N, $11^{\circ} 43$ ' 23” E, 400 m a.s.l.). The climatic conditions were typical of the Mediterranean area, with approximately $780 \mathrm{~mm}$ of rain per year (average figure for the period 2008-2012), mostly concentrated in Autumn (OctoberDecember) and Spring (March-May), with a dry summer period (JulyAugust) and with an average annual temperature of $13.5^{\circ} \mathrm{C}$.

In each location, a randomised block design with two replicates was performed. Five ancient bread wheat genotypes from the Tuscan germplasm were analysed: Verna (A), Inallettabile 96 (B), Andriolo (C), Frassineto (D), Gentil rosso (E). The modern variety, Palesio (F) was taken as the reference control. The ancient genotypes were evaluated either individually (pure) or in combination (mixture), taken two at a time, without repeats, in proportion of 1:1. Hence, there was a total of ten combinations (NC) of $\mathrm{n}$ elements taken two at a time, where $\mathrm{n}=$ number of items $(\mathrm{n}=5)$ and $\mathrm{k}=$ elements in any combination $(\mathrm{k}=2)$ :

$N C=\frac{\mathrm{n} !}{\mathrm{k} !(\mathrm{n}-\mathrm{k}) !}$

With $\mathrm{k}=2$ it is simplified in:

$N C=\frac{\mathrm{n}(\mathrm{n}-1)}{2}$

Overall, there were 16 theses in total ( 5 ancient varieties +10 ancient variety mixtures +1 modern variety) arranged in plots. The plots were randomly distributed for each replicate on each farm location. The plots (experimental units) were $15 \mathrm{~m}^{2}(3.0 \times 5.0 \mathrm{~m})$ in dimension.

The bread wheat varieties utilised in the experimental trial had the following characteristics:

- Andriolo is a variety with an unknown origin, most likely a selection of the Terricchio variety. It is characterised by high rusticity and is referred to as mountain wheat. It is currently registered in the Tuscan directory of conservation varieties.

- Frassineto was obtained in 1922 by Michahelles by pure line selection from Gentil rosso. It is characterised by high rusticity and is highly adaptable to different environments, particularly in hilly and mountainous regions. This variety is currently registered in the Tuscan directory as one of the conservation varieties.

- Gentil rosso was the parent variety used by Michahelles in breeding and is native to Central and Northern Italy. In the mid-1800s cultivation spread to the region of Emilia due to its high productivity, which was higher than the variety Rieti, commonly cultivated in that period. Gentil rosso is currently registered in the Tuscan directory of conservation varieties.

- Inallettabile 96 is a variety obtained by De Carolis, based on the indications of Todaro for the selection of the best spikes from the variety Inallettabile 38 , in turn selected from the French variety Hatif Inversable (obtained by Vilmorin in the early 1900s). This variety was short in length and resistant to lodging. In a short period of time, Inallettabile 96 supplanted Rieti and joined other varieties such as Gentil rosso (Failla and Funi, 2006). This variety was widely cultivated in Northern and Central Italy, predominantly in the lowlands but also in the hills and low mountains, and is currently registered in the Tuscan directory of conservation varieties.

- Verna was obtained by Gasparini in 1953 from the cross between Est Mottin $72 \mathrm{x}$ Mont Calme 245. This variety is suitable to mountainous areas above $600 \mathrm{~m}$ a.s.l. and it can be described as very rustic, with exceptional resistance to cold and rust and best suited to average to fertile lands. Verna was reinserted in the National Register since 2012.

- Palesio is an Italian variety registered in 2000 . This modern variety 
was obtained from the cross between Pandas $\times$ Recital, and classified as having superior baking quality.

The varieties, in all locations, were cultivated according to the requirements set for organic farming. No fertilisers were used during the course of cultivation. Therefore, the varieties used fertile residues in the soil derived from previous crops. Each experimental field formed part of a five-year rotation scheme as follows: grassland, renewal, cereals. The amount of seed used was based on the 1000 kernel weight and sowing density of 400 seeds per $\mathrm{m}^{2}$. In each location (for each thesis/plot), six plants were selected for the measurement of morphological parameters at full maturation. The following parameters were measured: plant height $(\mathrm{cm})$; number of internodes of the principal culm; total number of culms plant ${ }^{-1}$; total number of ears plant ${ }^{-1}$; straw weight of the plant (g); total ear weight (g), total number of kernels and kernel weight $(\mathrm{g})$ of the plant; length $(\mathrm{cm})$, weight $(\mathrm{g})$, number of spikelets, number of kernels, kernel weight $(\mathrm{g})$ of the main ear. of these parameters, only mean data of plant height, main ear length, and main ear weight have been reported in the Results, to leave more space for the presentation of technological and qualitative variables; all these parameters, however, have been utilised for the principal component analysis (PCA).

At harvest, all the entire plots were analysed for the following parameters: yield ( $\left.\mathrm{q} \cdot \mathrm{ha}^{-1}\right), 1000$ kernel weight $(\mathrm{g})$, test weight $\left(\mathrm{kg} \cdot \mathrm{hL} \mathrm{L}^{-1}\right)$. From each plot in each location, two grain samples of $100 \mathrm{~g}$ and $800 \mathrm{~g}$ respectively, were collected. Each $100 \mathrm{~g}$ sample was milled to produce whole-grain flour, which was stored at $-20^{\circ} \mathrm{C}$ for chemical analysis. Samples of $800 \mathrm{~g}$ were specially milled to produce flour for the rheological analyses.

\section{Macro- and microelements}

Carbon and nitrogen content was determined on whole-grain flour samples of 3-4 mg each, by means of a CHN elemental analyser (Thermo Fisher Scientific, Waltham, MA, USA). Total protein content was calculated using nitrogen to protein conversion Factor of 5.7. The macro- (Ca, K, Mg, Na and P) and microelements (Fe, Mn and $\mathrm{Zn}$ ) were measured by inductively coupled argon plasma emission spectroscopy (Thermo Fisher Scientific) as described previously (Ghiselli et al., 2015).

\section{Free and bound phenolic compounds}

The extraction of free (soluble) and bound (insoluble) phenolic compounds was performed according to Adom and Liu (2002) using a solution of EtOH: $\mathrm{H}_{2} \mathrm{O}$ 80:20 (v/v) to extract the soluble fraction. The pellet residue was subsequently extracted with an alkaline solvent $(0.5 \mathrm{~mL}$ $10 \mathrm{M} \mathrm{NaOH}+1.2 \mathrm{~mL}$ deionised water), and then with an acidic solvent $(0.9 \mathrm{~mL} 6 \mathrm{M} \mathrm{HCl})$, to solubilise the bound fraction. Polyphenol content in both the free and bound fractions was measured using the spectrophotometric Folin-Ciocalteu method (Lambda 20 Spectrophotometer, Perkin Elmer Corporation, Waltham, MA, USA) with gallic acid as the reference standard (Singleton et al., 1999).

\section{Free and bound flavonoid compounds}

The flavonoid content was determined similarly, using a colorimetric method with catechin as the reference standard (Adom et al., 2003). Total polyphenol and flavonoid contents were, respectively, presented as the sum total of the free and bound fractions. From the difference between total polyphenols and total flavonoids, the phenolic acid content was calculated.

\section{Antioxidant activity}

The radical scavenging activity of antioxidant active substances in the free and bound extracts was measured using the stable radical 2,2- diphenyl-1-picrylhydrazyl (DPPH), which becomes reduced by antioxidants to 2,2-diphenyl-1-picrylhydrazine (DPPHH), according to the spectrophotometric method of Brand-Williams et al. (1995). The efficient concentration (EC) represents the amount of antioxidant (A0) in the sample necessary to decrease the initial 2,2-diphenyl-1-picrylhydrazyl concentration by half $\left[\mathrm{EC}_{50}=(\mathrm{mol} / \mathrm{L}) \mathrm{AO} /(\mathrm{mol} / \mathrm{L}) \mathrm{DPPH}\right] . \mathrm{EC}_{50}$ was calculated for each sample from a calibration curve by linear regression, using solutions with different concentrations of DPPH. The higher the $\mathrm{EC}_{50}$ the less efficient the antioxidant activity of the sample. For clarity, the $\mathrm{EC}_{50}$ value for each of the sample was converted into antiradical power (ARP), using the following equation: ARP = $\left(1 / \mathrm{EC}_{50}\right) \times 100$. The higher the antiradical power value, the more efficient the radical scavenging activity of the sample.

\section{Rheological analysis}

To evaluate the bread-making quality of the different theses, grain samples for each plot were individually milled with a Chopin Dubois CD1 experimental mill (Chopin Technologies, Villeneuve-la-Garenne, France) to obtain white flour. The Chopin alveograph test was carried out on white flour with an aqueous solution at $2.5 \%$ of $\mathrm{NaCl}$ as described by UNI EN ISO 27971 (ISO, 2008) method for flour. It was used to assess dough strength ( $\mathrm{W}$ in $10^{-4} \mathrm{~J}$ ), tenacity ( $\mathrm{P}$ in $\mathrm{mm} \mathrm{H}_{2} \mathrm{O}$ ), extensibility ( $\mathrm{L}$ in $\mathrm{mm}$ ) and the tenacity/extensibility $(\mathrm{P} / \mathrm{L}$ in $\mathrm{mm}$ $\mathrm{H}_{2} \mathrm{O} \cdot \mathrm{mm}^{-1}$ ) ratio. The curves and parameters were computed with an Alveolink apparatus. The dry gluten, expressed as \% dry matter (DM), was determined on white flour ( $20 \mathrm{~g}$ ) mixed with a saline solution at $2.0 \% \mathrm{NaCl}$, and thereafter washed with a buffered saline solution in order to remove the starch and soluble proteins, according to the Italian official methodology (Italian Regulation, 1994).

\section{Statistical analysis}

Statistical analysis of the morphological, chemical and rheological variables was carried out according to the experimental design splitplot by adopting the mixed model analysis of variance (ANOVA). The Farms were considered as the main plot with random effect, and the Variety as the sub-plot with fixed effect. Given the experimental design hierarchy, two errors were used to verify the initial hypotheses. The significance of differences between the means was performed with the Tukey's multiple comparisons test, considering the probability $\mathrm{P}<5 \%$ $\left(^{*}\right) \mathrm{P}<1 \%\left({ }^{* *}\right)$. The correlation matrix was performed between variables. To visualise the relationship between variables a correlogram was calculated.

The multivariate statistical analysis using PCA was performed on the chemical and rheological variables to provide a representative evaluation of the varietal combinations considered. The PC with a sign value $>0.5$ were used to compute the Euclidean distance matrix. The cluster analysis was carried out according to the algorithm of Shan. Statistical packages used for processing were IBM SPSS Statistics 21 (ANOVA and PCA) and NT SYS pc version $2.20 \mathrm{~N}$ (Euclidean distance matrix and cluster analysis).

\section{Results}

\section{Morphological, commercial and rheological parameters}

The commercial and rheological parameters are of great interest for the bread making industry. For this reason, these parameters, together with the morphological parameters, are shown in Table 1. On the farm level, all parameters were significantly different, with the only exception of ear length and weight. In the farm, the yield showed variable trend ranging from 18 and $33 \mathrm{q} \cdot \mathrm{ha}^{-1}$. The 1000 kernel weight was with- 
in the range of $34-45 \mathrm{~g}$, the test weight between $77-79 \mathrm{~kg} \cdot \mathrm{hL}-1$ and the protein content between 10-14\%. Among the genotypes, all parameters reported in Table 1 were significantly different, with the exception of total protein. Considering the morphological traits, Gentil rosso was the genotype with the highest plant height, whilst the modern variety, Palesio, was the shortest; Gentil rosso had the longest main ear, and Inallettabile 96 the shortest. Hence, Gentil rosso and Inallettabile 96 were also the two varieties with the heaviest and lightest earweights, respectively. For production, Palesio and Inallettabile 96-Andriolo were the most productive, while Verna-Frassineto and Gentil rosso had the lowest yields. The highest values for 1000 kernel weight were observed in the ancient varieties (single and mixed) with a range from 38 to 43 $\mathrm{g}$, while for the modern variety, the average value was of $37 \mathrm{~g}$. The reverse trend occurred for the test weight, where Palesio showed significantly higher values than the old varieties. In turn, the latter did not vary between either varieties or mixtures, respectively, with the sole exception of the Verna-Frassineto, which was characterised by lower values. Regarding the dry gluten, Palesio showed the highest value as compared to the ancient varieties (single or mixed). The same result was observed for $\mathrm{W}$ value (dough strength). It is noteworthy that variety combinations, which included the varieties Verna, Inallettabile 96 and Frassineto, produced higher $\mathrm{W}$ values than the same varieties when cultivated singularly. Similarly, the rheological index, P (toughness), was found to be higher in the modern variety, whereas the ancient varieties showed lower values, varying from 28 to 43 . The $\mathrm{L}$ index (extensibility) was higher in the modern variety, but was only significantly higher than that of Gentil rosso and Frassineto. Regarding the P/L index, the ancient varieties showed balanced values within the optimal range of 0.4-0.7, with the exception of Gentil rosso and Gentil rosso-Inallettabile 96 with the highest values even compared to modern variety. Verna was the only variety that had $\mathrm{P} / \mathrm{L}$ values within the optimal range of reference in all environments (Figure 1).

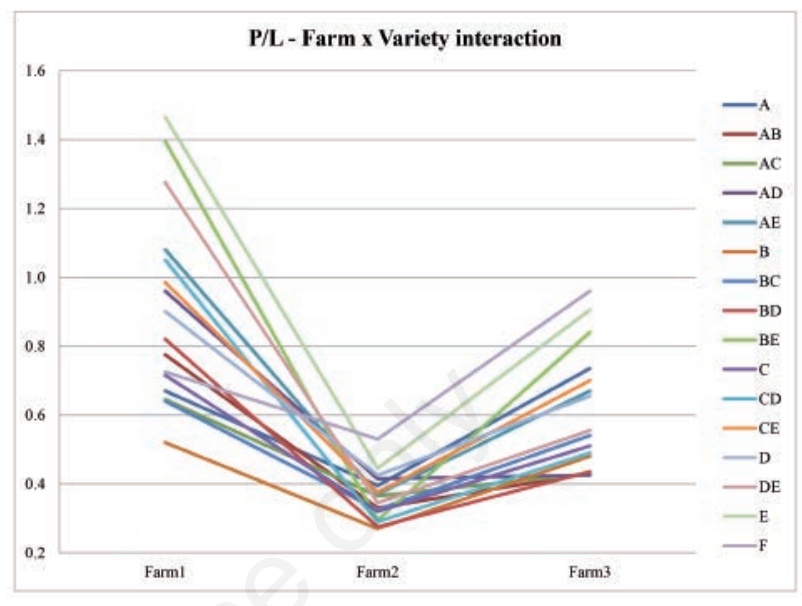

Figure 1. Farm $\times$ Variety interaction for the rheological index P/L.

Table 1. Mean data of the morphological, commercial and rheological parameters of the investigated farms and wheat varieties.

\begin{tabular}{|c|c|c|c|c|c|c|c|c|c|c|c|c|}
\hline & $\begin{array}{l}\text { Plant } \\
\text { height } \\
\text { cm }\end{array}$ & $\begin{array}{l}\text { Main } \\
\text { ear } \\
\text { length } \\
\text { cm }\end{array}$ & $\begin{array}{l}\text { Main } \\
\text { ear } \\
\text { weight } \\
\text { g }\end{array}$ & $\begin{array}{l}\text { Grain } \\
\text { yield } \\
\text { q ha-1 }^{-1}\end{array}$ & $\begin{array}{l}1000 \\
\text { kernel } \\
\text { weight } \\
\text { g }\end{array}$ & $\begin{array}{c}\text { Test } \\
\text { weight } \\
\mathrm{kg} \mathrm{hL}^{-1}\end{array}$ & $\begin{array}{c}\text { Total } \\
\text { protein } \\
\text { \% DM }\end{array}$ & $\begin{array}{l}\begin{array}{c}\text { Dry } \\
\text { gluten }\end{array} \\
\% \text { DM }\end{array}$ & $\begin{array}{c}\text { W } \\
\times 10^{-4} \mathrm{~J}\end{array}$ & $\begin{array}{l}\mathrm{mm} \\
\mathrm{H}_{2} \mathrm{O}\end{array}$ & $\mathrm{mm}$ & $\stackrel{\mathrm{mm}}{\mathrm{H}_{2} \mathrm{O} \cdot \mathrm{mm}^{-1}}$ \\
\hline Farm & $*$ & ns & ns & * & $* *$ & $*$ & $*$ & $* *$ & $* *$ & $* *$ & $* *$ & $*$ \\
\hline Farm 1 & 137.1 & 9.4 & 1.7 & 33.2 & 42.6 & 79.3 & 9.9 & 7 & 36 & 30 & 35 & 0.9 \\
\hline Farm 2 & 118.4 & 9.7 & 1.8 & 21.9 & 34.1 & 77.1 & 14.2 & 14 & 81 & 34 & 95 & 0.4 \\
\hline Farm 3 & 128.4 & 10.0 & 1.8 & 18.4 & 44.6 & 78.1 & 13.7 & 13 & 100 & 44 & 78 & 0.6 \\
\hline Variety & $* *$ & $* *$ & $* *$ & * & $*$ & $* *$ & ns & $* *$ & $* *$ & $* *$ & $* *$ & $* *$ \\
\hline A & $126.0^{\text {bd }}$ & $8.7^{\mathrm{df}}$ & $1.6^{\mathrm{ad}}$ & $22.4^{\mathrm{ab}}$ & $37.7^{\mathrm{cd}}$ & $77.2^{\text {bd }}$ & 12.7 & $11.2^{\mathrm{ac}}$ & $73^{\text {be }}$ & $37 \mathrm{bc}$ & $68^{\mathrm{ab}}$ & $0.6^{\mathrm{cg}}$ \\
\hline $\mathrm{AB}$ & $122.2^{\mathrm{cd}}$ & $8.3^{\mathrm{df}}$ & $1.5^{\mathrm{bd}}$ & $23.7^{\mathrm{ab}}$ & $39.4^{\text {ad }}$ & $77.6^{\text {bd }}$ & 13.6 & $12.2^{\mathrm{ab}}$ & $74^{\text {bd }}$ & $35^{\text {bd }}$ & $79^{a}$ & $0.5^{\mathrm{dg}}$ \\
\hline $\mathrm{AC}$ & $132.2^{\mathrm{ac}}$ & $9.2^{\mathrm{df}}$ & $1.8^{\mathrm{ad}}$ & $21.9^{\mathrm{ab}}$ & $38.6^{\text {bd }}$ & $77.0^{\mathrm{cd}}$ & 12.9 & $11.8^{\mathrm{ac}}$ & $81^{\mathrm{b}}$ & $36^{\text {bd }}$ & $81^{\mathrm{a}}$ & $0.5^{\mathrm{fg}}$ \\
\hline $\mathrm{AD}$ & $133.0^{\mathrm{ac}}$ & $10.3^{\text {bd }}$ & $1.8^{\mathrm{ad}}$ & $20.6^{\mathrm{b}}$ & $41.5^{\text {ad }}$ & $76.9^{\mathrm{d}}$ & 12.3 & $11.1^{\mathrm{ac}}$ & $73^{\text {be }}$ & $35^{\text {bd }}$ & $73^{\mathrm{ab}}$ & $0.6^{\mathrm{cg}}$ \\
\hline $\mathrm{AE}$ & $135.0^{\mathrm{ac}}$ & $10.2^{\text {bd }}$ & $1.8^{\mathrm{ad}}$ & $23.8^{\mathrm{ab}}$ & $38.6^{\text {bd }}$ & $78.3^{\text {bd }}$ & 12.6 & $11.0^{\mathrm{ac}}$ & $76^{\mathrm{bc}}$ & $39^{\mathrm{bc}}$ & $68^{\mathrm{ab}}$ & $0.7^{\text {be }}$ \\
\hline B & $110.1^{d}$ & $7.4^{\mathrm{f}}$ & $1.4^{\mathrm{d}}$ & $21.8^{\mathrm{ab}}$ & $40.5^{\text {ad }}$ & $77.5^{\mathrm{bd}}$ & 12.6 & $12.2^{\mathrm{ab}}$ & $55^{\mathrm{e}}$ & $28^{d}$ & $71^{\mathrm{ab}}$ & $0.4^{g}$ \\
\hline $\mathrm{BC}$ & $127.8^{\mathrm{ac}}$ & $8.1^{\text {ef }}$ & $1.4^{\mathrm{cd}}$ & $30.9^{\mathrm{a}}$ & $39.9^{\text {ad }}$ & $77.8^{\text {bd }}$ & 13.1 & $11.5^{\mathrm{ac}}$ & $57^{\mathrm{de}}$ & $28^{\mathrm{d}}$ & $66^{\mathrm{ab}}$ & $0.5^{\mathrm{eg}}$ \\
\hline $\mathrm{BD}$ & $130.9^{\mathrm{ac}}$ & $9.6^{\mathrm{de}}$ & $1.9^{\mathrm{ad}}$ & $26.1^{\mathrm{ab}}$ & $43.1^{\mathrm{a}}$ & $78.1^{\text {bd }}$ & 12.6 & $10.4^{\mathrm{bc}}$ & $60^{\text {ce }}$ & $30^{\text {cd }}$ & $73^{\mathrm{ab}}$ & $0.5^{\mathrm{dg}}$ \\
\hline $\mathrm{BE}$ & $126.6^{\mathrm{bd}}$ & $9.9 \mathrm{ce}$ & $1.7^{\mathrm{ad}}$ & $24.9^{\mathrm{ab}}$ & $41.7^{\mathrm{ac}}$ & $78.7^{\mathrm{bd}}$ & 11.4 & $10.4^{b c}$ & $60^{\text {ce }}$ & $36^{\text {bd }}$ & $61^{\mathrm{ab}}$ & $0.8^{\mathrm{ab}}$ \\
\hline $\mathrm{C}$ & $135.5^{\mathrm{ac}}$ & $8.6^{\mathrm{df}}$ & $1.5^{\mathrm{bd}}$ & $24.6^{\mathrm{ab}}$ & $40.4^{\text {ad }}$ & $77.1^{\text {cd }}$ & 12.7 & $10.6^{\mathrm{bc}}$ & $64^{\text {be }}$ & $31^{\mathrm{cd}}$ & $72^{\mathrm{ab}}$ & $0.5^{\mathrm{cg}}$ \\
\hline $\mathrm{CD}$ & $132.3^{\mathrm{ac}}$ & $9.8^{\mathrm{ce}}$ & $1.8^{\mathrm{ad}}$ & $26.1^{\mathrm{ab}}$ & $41.7^{\mathrm{ac}}$ & $77.5^{\mathrm{bd}}$ & 12.5 & $10.3^{c}$ & 59 ce & $30^{\mathrm{cd}}$ & $69^{\mathrm{ab}}$ & $0.6^{\mathrm{cg}}$ \\
\hline$\overline{\mathrm{CE}}$ & $139.7^{\mathrm{ab}}$ & $10.3^{\text {bd }}$ & $1.9^{\mathrm{ad}}$ & $26.2^{\mathrm{ab}}$ & $40.7^{\text {ad }}$ & $78.5^{\mathrm{bd}}$ & 12.8 & $10.1^{\mathrm{c}}$ & $69^{\text {be }}$ & $37^{\mathrm{bc}}$ & $66^{\mathrm{ab}}$ & $0.7^{\mathrm{bf}}$ \\
\hline D & $133.9^{\mathrm{ac}}$ & $11.7^{\mathrm{ac}}$ & $1.9^{\mathrm{ac}}$ & $26.7^{\mathrm{ab}}$ & $42.2^{\mathrm{ab}}$ & $78.4^{\text {bd }}$ & 12.1 & $10.8^{b c}$ & $57^{\mathrm{de}}$ & $33^{\mathrm{cd}}$ & $56^{\mathrm{b}}$ & $0.7^{\mathrm{bf}}$ \\
\hline $\mathrm{DE}$ & $139.8^{\mathrm{ab}}$ & $11.9^{\mathrm{ab}}$ & $2.0^{\mathrm{ac}}$ & $22.4^{\mathrm{ab}}$ & $42.6^{\mathrm{ab}}$ & $78.8^{\mathrm{bc}}$ & 13.0 & $11.3^{\mathrm{ac}}$ & $75^{\text {bd }}$ & $38^{\mathrm{bc}}$ & $70^{\mathrm{ab}}$ & $0.7^{\mathrm{ad}}$ \\
\hline $\mathrm{E}$ & $145.0^{\mathrm{a}}$ & $12.4^{\mathrm{a}}$ & $2.2^{\mathrm{a}}$ & $20.6^{\mathrm{b}}$ & $40 . g^{\text {ad }}$ & $79.0^{\mathrm{b}}$ & 12.2 & $11.6^{\mathrm{ac}}$ & $76^{\mathrm{bc}}$ & $43^{b}$ & $57^{\mathrm{b}}$ & $0.9^{\mathrm{a}}$ \\
\hline $\mathrm{F}$ & $77.2^{\mathrm{e}}$ & $8.8^{\mathrm{df}}$ & $2.1^{a b}$ & $31.0^{\mathrm{a}}$ & $37.3^{\mathrm{d}}$ & $82.2^{\mathrm{a}}$ & 12.5 & $12.8^{\mathrm{a}}$ & $142^{\mathrm{a}}$ & $57^{a}$ & $82^{a}$ & $0.7^{\mathrm{ac}}$ \\
\hline Farm $\times$ Variety & ns & ns & ns & ns & $*$ & ns & ns & ns & $* *$ & ns & $* *$ & $* *$ \\
\hline
\end{tabular}

DM, dry matter; A, Verna; B, Inallettabile 96; C, Andriolo; D, Frassineto; E, Gentil rosso; F, Palesio. ns, not significant. Means followed by different letters were statistically different at P $\leq 0.05(*)$ or P $\leq 0.01(* *)$. 


\section{Mineral element content}

The macro- and microelement contents, which are both nutritionally and functionally important, are presented in Table 2. On the farm level, $K$ varied significantly and $P$ varied highly significantly, within a range of 2777-3545 and $2626-4043 \mathrm{mg} \cdot \mathrm{kg} \mathrm{DM}^{-1}$ respectively. Mn varied significantly and Zn highly significantly, within a range of 26-44 and 35-52 $\mathrm{mg} \cdot \mathrm{kg} \mathrm{DM}^{-1}$ respectively.

Ca was significantly different between varieties. The Andriolo-Gentil rosso mixture and Gentil rosso were the richest in this element, whilst Palesio had the lowest content. A higher $\mathrm{K}$ content was detected in Frassineto that influenced the combinations, all of which contained very high levels of this element. Palesio, on the contrary, was the variety with the lowest content. Andriolo-Frassineto was rich in Mn, whilst Verna and Verna-Inallettabile 96 had the lowest content. Andriolo and Palesio respectively showed the highest and lowest $\mathrm{Zn}$ content. $\mathrm{K}$ and $P$ contents were shown to be significant for the Farm $\times$ Variety interaction.

\section{Secondary metabolite content}

Secondary metabolite content and related anti-oxidant capacity are important functional characteristics. The polyphenol and flavonoid contents, as well as ARP, are presented in Table 3. The environment (Farm) produced significant differences in the following parameters: free and total polyphenols, bound and total flavonoids, phenolic acids, bound and total ARP. The total polyphenol levels ranged from 3.747 to $3.315 \mathrm{mg} \cdot \mathrm{g} \mathrm{DM}^{-1}$, whilst the range for free polyphenols was $1.054-0.835 \mathrm{mg} \cdot \mathrm{g} \mathrm{DM}^{-1}$. The trend in polyphenol content was related to ARP on the farm level. For genotype, significant differences were found for all the variables tested with the exception of bound polyphenols, free flavonoids and free ARP. Verna and Verna-Inallettabile 96 reported the highest free polyphenols and phenolic acids, whilst Palesio had the lowest values. Verna had the highest total polyphenols, whilst Frassineto-Gentil rosso had the lowest values. The content of bound and total flavonoids were significant. In both cases, Inallettabile 96-Gentil rosso was the mixture with the lowest value, while Frassineto both alone and in mixture with Gentil rosso showed the highest values of flavonoids. Bound ARP was found to be higher in Verna and lower in Palesio, Gentil rosso, and the VernaFrassineto, Inallettabile 96-Gentil rosso, Frassineto-Gentil rosso mixtures. Verna also showed the highest total ARP, whilst Verna-Frassineto and Inallettabile 96 had the lowest values. Therefore, polyphenol content had a greater influence in determining the ARP values than flavonoid content at the genotype level.

The Farm $\times$ Variety interaction showed significant differences for the free, bound and total polyphenol content, bound and total flavonoids, phenolic acids and bound ARP.

\section{Pearson correlations and principal component analysis}

In order to confirm the relationships among the technological properties, mineral elements and functional properties, considering the Pearson coefficients, a general correlogram was calculated considering only the ancient varieties, and excluding the modern variety, Palesio (Figure 2). The general correlogram showed a predictable positive cor-

Table 2. Macro and microelement content in the investigated farms and wheat varieties.

\begin{tabular}{|c|c|c|c|c|c|c|c|c|}
\hline & $\mathrm{Ca}$ & K & Mg & $\begin{array}{l}\mathrm{Na} \\
\mathrm{m}\end{array}$ & $M^{-1}$ & $\mathrm{Fe}$ & Mn & $\mathrm{Zn}$ \\
\hline Farm & ns & $*$ & ns & ns & $* *$ & ns & $*$ & $* *$ \\
\hline Farm 1 & 379.48 & 3545.14 & 1356.09 & 16.85 & 2841.631 & 29.432 & 26.34 & 34.85 \\
\hline Farm 2 & 510.85 & 2777.28 & 1342.57 & 16.83 & 2625.844 & 37.525 & 36.07 & 51.92 \\
\hline Farm 3 & 441.47 & 3462.11 & 1496.35 & 15.32 & 4042.763 & 40.705 & 44.33 & 51.23 \\
\hline Variety & $* *$ & $* *$ & ns & ns & ns & ns & $* *$ & $* *$ \\
\hline A & $344.18^{\mathrm{de}}$ & $3323.55^{\text {ad }}$ & 1411.31 & 18.59 & 3374.82 & 36.35 & $31.66^{\mathrm{b}}$ & $49.19^{\mathrm{ab}}$ \\
\hline$\overline{A B}$ & $375.79^{\text {be }}$ & $3136.04^{\mathrm{ce}}$ & 1269.83 & 14.21 & 3135.91 & 33.38 & $31.35^{b}$ & $46.02^{\mathrm{ac}}$ \\
\hline $\mathrm{AC}$ & $420.95^{\mathrm{ae}}$ & $3217.50^{\text {bd }}$ & 1492.77 & 17.26 & 3329.58 & 35.71 & $34.20^{\mathrm{ab}}$ & $49.78^{\mathrm{ab}}$ \\
\hline$\overline{A D}$ & $428.71^{\text {ae }}$ & $3363.14^{\mathrm{ac}}$ & 1264.77 & 15.94 & 3180.38 & 34.12 & $33.66^{\mathrm{ab}}$ & $45.02^{\mathrm{ac}}$ \\
\hline $\mathrm{AE}$ & $465.62^{\text {ad }}$ & $3307.21^{\text {ad }}$ & 1520.55 & 16.18 & 3271.39 & 35.22 & $34.88^{\mathrm{ab}}$ & $45.98^{a c}$ \\
\hline B & $372.43^{\mathrm{ce}}$ & $3068.49 \mathrm{de}$ & 1362.78 & 12.88 & 3108.41 & 30.36 & $34.68^{\mathrm{ab}}$ & $43.02^{b c}$ \\
\hline $\mathrm{BC}$ & $434.95^{\mathrm{ae}}$ & $3220.50^{\mathrm{bd}}$ & 1506.19 & 15.38 & 3220.44 & 45.85 & $37.33^{\mathrm{ab}}$ & $48.99^{a c}$ \\
\hline $\mathrm{BD}$ & $426.72^{\mathrm{ae}}$ & $3372.19 \mathrm{ac}$ & 1453.36 & 15.78 & 3130.03 & 32.25 & $37.10^{a b}$ & $43.73^{\mathrm{ac}}$ \\
\hline $\mathrm{BE}$ & $487.05^{\text {ad }}$ & $3060.88^{\text {de }}$ & 1270.50 & 15.58 & 2937.44 & 31.71 & $34.38^{\mathrm{ab}}$ & $41.17^{b c}$ \\
\hline $\mathrm{C}$ & $525.06^{\mathrm{ac}}$ & $3277.65^{\text {ad }}$ & 1462.69 & 18.08 & 3260.68 & 37.70 & $37.68^{\mathrm{ab}}$ & $52.28^{\mathrm{a}}$ \\
\hline $\mathrm{CD}$ & $474.96^{\text {ad }}$ & $3457.14^{\mathrm{ab}}$ & 1381.66 & 17.77 & 3206.13 & 37.69 & $38.46^{\mathrm{a}}$ & $48.15^{\mathrm{ac}}$ \\
\hline$\overline{\mathrm{CE}}$ & $537.81^{\mathrm{a}}$ & $3249.29^{\mathrm{bd}}$ & 1437.70 & 16.00 & 3063.33 & 35.92 & $37.39^{a b}$ & $48.61^{\mathrm{ac}}$ \\
\hline D & $438.40^{\mathrm{ae}}$ & $3548.77^{a}$ & 1329.66 & 18.50 & 3272.51 & 44.76 & $36.42^{\mathrm{ab}}$ & $43.12^{\mathrm{bc}}$ \\
\hline $\mathrm{DE}$ & $528.34^{\mathrm{ab}}$ & $3402.80^{\mathrm{ac}}$ & 1498.59 & 17.68 & 3324.67 & 33.82 & $36.81^{\mathrm{ab}}$ & $46.07^{\mathrm{ac}}$ \\
\hline E & $533.12^{\mathrm{a}}$ & $3263.35^{\text {ad }}$ & 1357.72 & 15.05 & 3019.02 & 35.99 & $35.83^{\mathrm{ab}}$ & $44.43^{\mathrm{ac}}$ \\
\hline $\bar{F}$ & $308.87^{\mathrm{e}}$ & $2915.65^{\mathrm{e}}$ & 1353.34 & 16.42 & 2886.53 & 33.37 & $37.42^{\mathrm{ab}}$ & $40.38^{c}$ \\
\hline Farm $\times$ Variety & ns & * & ns & ns & $*$ & ns & ns & ns \\
\hline
\end{tabular}

Ca, calcium; K, potassium; Mg, magnesium; Na, sodium; P, phosphorus; Mn, manganese; Zn, zinc; DM, dry matter; A, Verna; B, Inallettabile 96; C, Andriolo; D, Frassineto; E, Gentil rosso; F, Palesio. ns, not significant. Means followed by different letters were statistically different at $\mathrm{P} \leq 0.05\left(^{*}\right)$ or $\mathrm{P} \leq 0.01(* *)$. 
relation between the variables of the same group, such as the rheological properties (W, P, gluten and proteins content), as well as between the characteristics related to the presence of secondary metabolites (polyphenols content and antioxidant activity).

Minerals (Figure 2) were positively related to the rheological properties (W, gluten and protein), with the sole exception of $K$ that behaves in the opposite manner to the other mineral elements. The elements, $\mathrm{Ca}, \mathrm{Mn}, \mathrm{P}$ and $\mathrm{Zn}$ were strictly correlated to each other while $\mathrm{K}$ was positively associated with only $\mathrm{P}$, and negatively associated with $\mathrm{Ca}$ and $\mathrm{Zn}$. $\mathrm{K}$ was also inversely related to the protein content, $\mathrm{W}$, gluten, polyphenols and phenolic acids. Polyphenols and ARP were positively correlated. Unlike the polyphenol component, total ARP was negatively correlated to both gluten content and gluten strength (W and P). No relationship was evident with protein content.

By analysing the interactions between the factors not associated within the same group, some interesting considerations became evident: in particular was the positive correlation between the content in polyphenols and gluten, and the negative correlation between the parameter $\mathrm{W}$ and ARP. The negative correlation between $\mathrm{W}$ and ARP has been split up to check the behaviour at the farm level (Figure 3). In each Farm the trend of the correlation was positive. The negative trend that was detected in the general correlation was due to the low values of $\mathrm{W}$ detected in Farm 1.

Figure 4 shows the two-dimensional distribution for the first two PCs for all variables considered. PCA was performed taking into account 27 significant variables of ANOVA and applied Varimax rotation for the PC transformation. The first ten PCs with an Eigen value $>1$ explain approximately $89 \%$ of the total variance, whereas the first 2 PCs describe, respectively, 21 and $11 \%$ of the variance. Some parameters, such as total protein and dry gluten content, were positively correlated with the $1^{\text {st }}$ axis ( $\mathrm{PC1}$ ) in the order of 0.78 and 0.80 , respectively. $\mathrm{P} / \mathrm{L}$ was found to be negatively correlated $(-0.89)$ with the $1^{\text {st }}$ axis. P element is positively correlated $(0.92)$ with the $2^{\text {nd }}$ axis (PC2). The PCA showed a marked effect of the environment (identified with the culti-

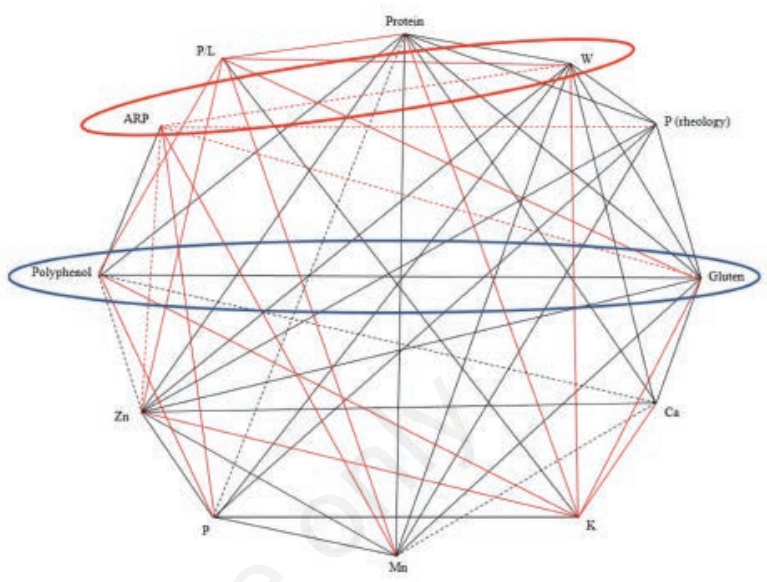

Figure 2. General correlogram of all variables. Black and red lines indicate a positive and negative correlation respectively. Solid and dashed lines are respectively $\mathrm{P}<0.01$ and $\mathrm{P}<0.05$ significance.

Table 3. Polyphenol, flavonoid, phenolic acid content and antiradical power in the investigated farms and wheat varieties.

\begin{tabular}{|c|c|c|c|c|c|c|c|c|c|c|}
\hline & $\begin{array}{c}\text { Free } \\
\text { polyph. }\end{array}$ & $\begin{array}{l}\text { Bound } \\
\text { polyph. }\end{array}$ & $\begin{array}{c}\text { Total } \\
\text { polyph. }\end{array}$ & $\begin{array}{l}\text { Free } \\
\text { flav. }\end{array}$ & $\begin{array}{c}\text { Bound } \\
\text { flav. } \\
\text { mg g DM-1 }\end{array}$ & $\begin{array}{l}\text { Total } \\
\text { flav. }\end{array}$ & $\begin{array}{c}\text { Phenolic } \\
\text { acid }\end{array}$ & $\begin{array}{l}\text { Free } \\
\text { ARP }\end{array}$ & $\begin{array}{l}\text { Bound } \\
\text { ARP }\end{array}$ & $\begin{array}{l}\text { Total } \\
\text { ARP }\end{array}$ \\
\hline Farm & $* *$ & $* *$ & $* *$ & ns & ns & ns & $* *$ & $* *$ & $* *$ & $* *$ \\
\hline Farm 1 & 0.8354 & 2.5304 & 3.3658 & 0.1713 & 0.6667 & 0.8380 & 2.5278 & 4.2720 & 12.3616 & 16.6336 \\
\hline $\begin{array}{l}\text { Farm } 2 \\
\text { Farm } 3\end{array}$ & $\begin{array}{l}0.9608 \\
1.0539\end{array}$ & $\begin{array}{l}2.7863 \\
2.2610\end{array}$ & $\begin{array}{l}3.7471 \\
3.3149\end{array}$ & $\begin{array}{l}0.1574 \\
0.1481\end{array}$ & $\begin{array}{l}0.6405 \\
0.6304\end{array}$ & $\begin{array}{l}0.7978 \\
0.7784\end{array}$ & 2.9493 & $\begin{array}{l}4.6806 \\
40691\end{array}$ & 11.7423 & 16.4230 \\
\hline Variety & $* *$ & ns & $* *$ & ns & $* *$ & $*$ & $* *$ & ns & $* *$ & $*$ \\
\hline A & $1.044^{\mathrm{a}}$ & 2.644 & $3.688^{\mathrm{a}}$ & 0.194 & $0.639^{\mathrm{ab}}$ & $0.833^{\mathrm{ab}}$ & $2.855^{\mathrm{a}}$ & 4.288 & $13.382^{\mathrm{a}}$ & $17.669^{\mathrm{a}}$ \\
\hline$\overline{\mathrm{AB}}$ & $1.048^{\mathrm{a}}$ & 2.574 & $3.622^{2 \mathrm{ab}}$ & 0.146 & $0.582^{\mathrm{ab}}$ & $0.727^{\mathrm{ab}}$ & $2.895^{\mathrm{a}}$ & 4.033 & $11.615^{\mathrm{ab}}$ & $15.648^{\mathrm{ab}}$ \\
\hline $\mathrm{AC}$ & $1.017^{\mathrm{ab}}$ & 2.477 & $3.493^{\mathrm{ad}}$ & 0.192 & $0.62 g^{\mathrm{ab}}$ & $0.821^{\mathrm{ab}}$ & $2.673^{\mathrm{ab}}$ & 4.518 & $12.325^{\mathrm{ab}}$ & $16.843^{\mathrm{ab}}$ \\
\hline$\overline{\mathrm{AD}}$ & $0.946^{\mathrm{ac}}$ & 2.478 & $3.424^{\text {ad }}$ & 0.156 & $0.636^{\mathrm{ab}}$ & $0.791^{\mathrm{ab}}$ & $2.633^{\mathrm{ab}}$ & 4.466 & $10.451^{b}$ & $14.918^{b}$ \\
\hline $\mathrm{AE}$ & $0.938^{\mathrm{ac}}$ & 2.642 & $3.580^{\mathrm{ad}}$ & 0.198 & $0.670^{\mathrm{ab}}$ & $0.867^{\mathrm{a}}$ & $2.712^{\mathrm{ab}}$ & 4.454 & $11.811^{\mathrm{ab}}$ & $16.265^{\mathrm{ab}}$ \\
\hline B & $0.919^{a c}$ & 2.429 & $3.348^{\text {bd }}$ & 0.143 & $0.581^{\mathrm{ab}}$ & $0.724^{\mathrm{ab}}$ & $2.624^{\mathrm{ab}}$ & 3.786 & $11.319^{\mathrm{ab}}$ & $15.105^{b}$ \\
\hline $\mathrm{BC}$ & $0.919^{\mathrm{ac}}$ & 2.683 & $3.602^{\mathrm{ab}}$ & 0.143 & $0.679^{\mathrm{ab}}$ & $0.822^{\mathrm{ab}}$ & $2.780^{\mathrm{ab}}$ & 4.000 & $12.289^{\mathrm{ab}}$ & $16.289^{\mathrm{ab}}$ \\
\hline $\mathrm{BD}$ & $0.953^{\mathrm{ac}}$ & 2.410 & $3.362^{\text {bd }}$ & 0.153 & $0.695^{\mathrm{ab}}$ & $0.848^{\mathrm{ab}}$ & $2.514^{\mathrm{b}}$ & 4.439 & $12.295^{\mathrm{ab}}$ & $16.735^{\mathrm{ab}}$ \\
\hline $\mathrm{BE}$ & $0.916^{\mathrm{ac}}$ & 2.544 & $3.460^{\mathrm{ad}}$ & 0.132 & $0.578^{b}$ & $0.710^{\mathrm{b}}$ & $2.750^{\mathrm{ab}}$ & 4.249 & $11.158^{\mathrm{b}}$ & $15.406^{\mathrm{ab}}$ \\
\hline $\mathrm{C}$ & $0.945^{\mathrm{ac}}$ & 2.532 & $3.477^{\mathrm{ad}}$ & 0.161 & $0.634^{\mathrm{ab}}$ & $0.794^{\mathrm{ab}}$ & $2.683^{\mathrm{ab}}$ & 3.914 & $12.074^{\mathrm{ab}}$ & $15.987^{\mathrm{ab}}$ \\
\hline CD & $0.888^{\mathrm{bc}}$ & 2.422 & $3.310^{\mathrm{cd}}$ & 0.153 & $0.665^{\mathrm{ab}}$ & $0.818^{a b}$ & $2.492^{b}$ & 4.297 & $12.216^{\mathrm{ab}}$ & $16.513^{\mathrm{ab}}$ \\
\hline $\mathrm{CE}$ & $0.967^{\mathrm{ac}}$ & 2.550 & $3.517^{\mathrm{ad}}$ & 0.159 & $0.652^{\mathrm{ab}}$ & $0.811^{\mathrm{ab}}$ & $2.706^{\mathrm{ab}}$ & 4.523 & $11.718^{\mathrm{a} b}$ & $16.241^{\mathrm{ab}}$ \\
\hline D & $1.012^{\mathrm{ab}}$ & 2.576 & $3.588^{a c}$ & 0.156 & $0.697^{\mathrm{a}}$ & $0.853^{\mathrm{ab}}$ & $2.735^{\mathrm{ab}}$ & 4.560 & $12.358^{\mathrm{a} b}$ & $16.917^{\mathrm{ab}}$ \\
\hline $\mathrm{DE}$ & $0.902^{\mathrm{ac}}$ & 2.399 & $3.301^{\mathrm{d}}$ & 0.145 & $0.669^{\mathrm{ab}}$ & $0.814^{\mathrm{ab}}$ & $2.487^{\mathrm{b}}$ & 4.499 & $11.088^{b}$ & $15.588^{\mathrm{ab}}$ \\
\hline E & $0.938^{\mathrm{ac}}$ & 2.552 & $3.490^{\mathrm{ad}}$ & 0.142 & $0.680^{\mathrm{ab}}$ & $0.822^{\mathrm{ab}}$ & $2.669^{\mathrm{ab}}$ & 4.830 & $10.805^{b}$ & $15.636^{\mathrm{ab}}$ \\
\hline $\mathrm{F}$ & $0.850^{c}$ & 2.503 & $3.353^{\mathrm{bd}}$ & 0.172 & $0.649^{\mathrm{ab}}$ & $0.821^{\mathrm{ab}}$ & $2.532^{\mathrm{b}}$ & 4.594 & $11.224^{b}$ & $15.818^{\mathrm{ab}}$ \\
\hline Farm $\times$ Variety & $* *$ & $* *$ & $* *$ & ns & $* *$ & $*$ & $* *$ & ns & * & ns \\
\hline
\end{tabular}

ARP, antiradical power; DM, dry matter; A, Verna; B, Inallettabile 96; C, Andriolo; D, Frassineto; E, Gentil rosso; F, Palesio; ns, not significant. Means followed by different letters were statistically different at P $\leq 0.05$ $(*)$ or $\mathrm{P} \leq 0.01(* *)$. 
vation farm) on the samples analysed, with respect to genotype. This led to a strong centralisation of samples, especially those of Farm 2 and Farm 3 that formed two well-defined clusters.

\section{Discussion}

The purpose of the research was to characterise the commercial, technological and functional qualities of ancient Tuscan varieties, cultivated both singularly and in mixtures in different environments. The modern variety, Palesio, was used as a reference, as modern varieties were developed particularly for improved rheological properties. The results of the present study did not reveal substantial improvements in the variables measured when varieties were cultivated in mixtures. However, the study did reveal various interesting trends that are warranting of further investigation.

Cultivation in mixtures resulted in a moderate increase in commer-
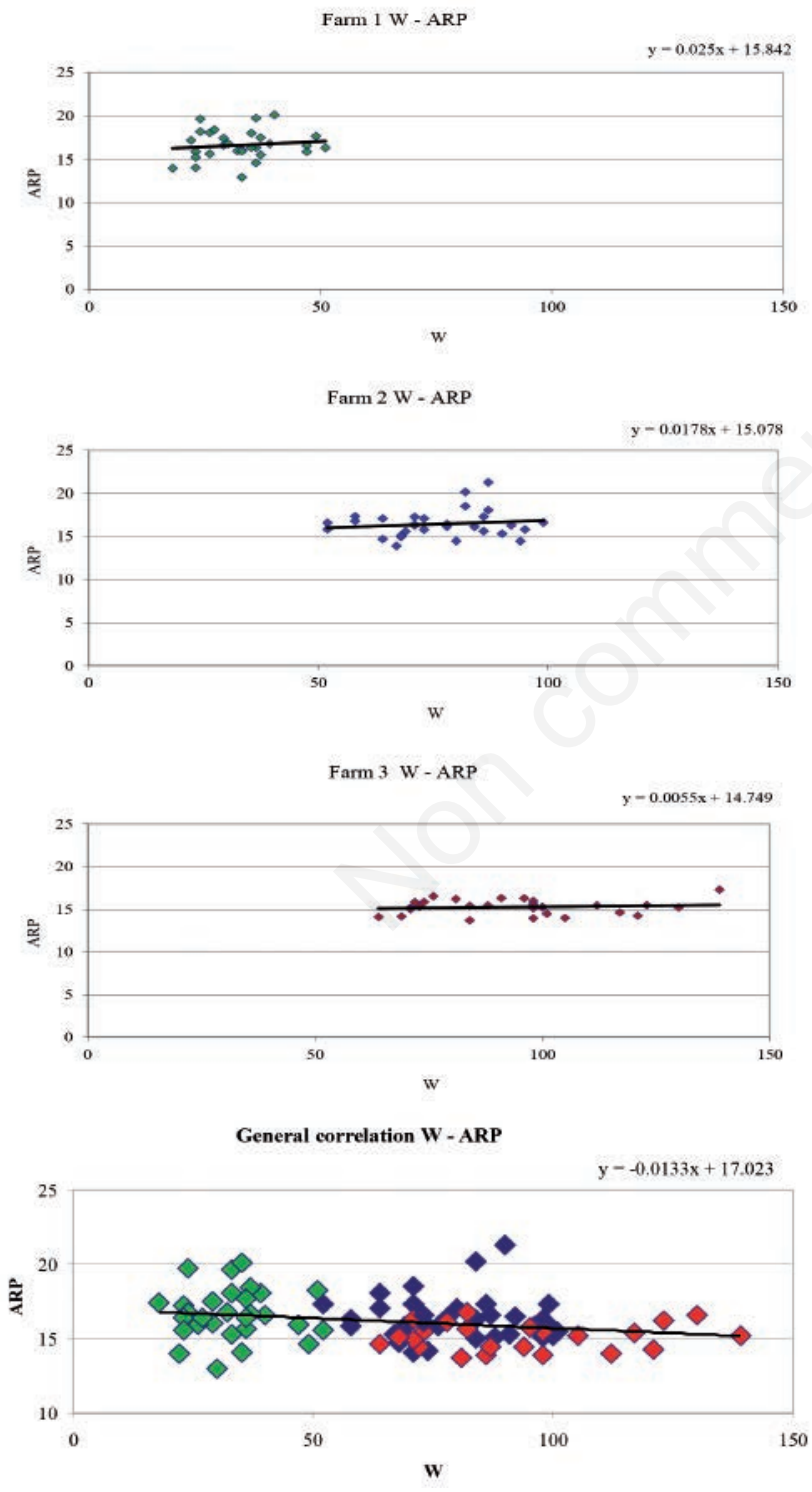

Figure 3. W - antiradical power (ARP) correlation at Farm level and general W - ARP correlation. cial parameters such as yield, 1000 kernel weight and test weight for some genotypes (Inallettabile 96, Andriolo and Verna), similar to that reported previously (Garret and Mundt, 1999; Finck et al., 2000; Swanston et al., 2005). The present work is the first to report results comparing rheological and functional parameters between single varieties and mixtures. As with the commercial properties mentioned above, a similar trend was observed for the rheological parameter, $\mathrm{W}$. The ancient varieties generally have a lower $\mathrm{W}$ in comparison to the modern variety, Palesio. However, of great interest, is that the mixtures containing the variety Verna showed higher $\mathrm{W}$ values with a more balanced $\mathrm{P} / \mathrm{L}$ ratio. Mixtures were also interesting for various mineral elements. Ca, which is low in single cultures of Verna and Inallettabile 96, was higher when these varieties were cultivated in mixtures with Gentil rosso. Frassineto and mixtures containing Frassineto were higher in $\mathrm{K}$ than other varieties and other mixtures.

Major differences between the ancient varieties and the modern variety were obtained for morphological and commercial parameters. Plant height of the ancient varieties was on average $54 \mathrm{~cm}$ greater than Palesio. Moreover, yield in the ancient varieties was lower than the modern variety but also lower than that reported for the same varieties in previous work (Guarda et al., 2004; Di Silvestro et al., 2012). The reason is attributable to the dry season in which the experiment was carried out. The least productive theses were Gentil rosso and the VernaFrassineto mixture. The kernels of Palesio were smaller than those of the ancient varieties, as was reported previously by Di Silvestro et al. (2012). Test weight is one of the most important qualitative parameters in the commercialisation of wheat. All ancient genotypes in the present study showed values that were higher than the minimum value required for the sale of wheat $\left(>75 \mathrm{~kg} \cdot \mathrm{hL}^{-1}\right)$ and higher than those reported previously (Guarda et al., 2004; Di Silvestro et al., 2012).

Rheological properties, important for the bread-making process, were strongly influenced by genotype. The greatest difference between ancient varieties and the modern variety was shown for the value, $\mathrm{W}$ or dough strength. All ancient varieties were below the minimum acceptable value of 150, required for baking (ranging between 55 and 81), with the modern variety showing a value of 142 . However, of great interest, is that the mixtures containing the variety Verna showed

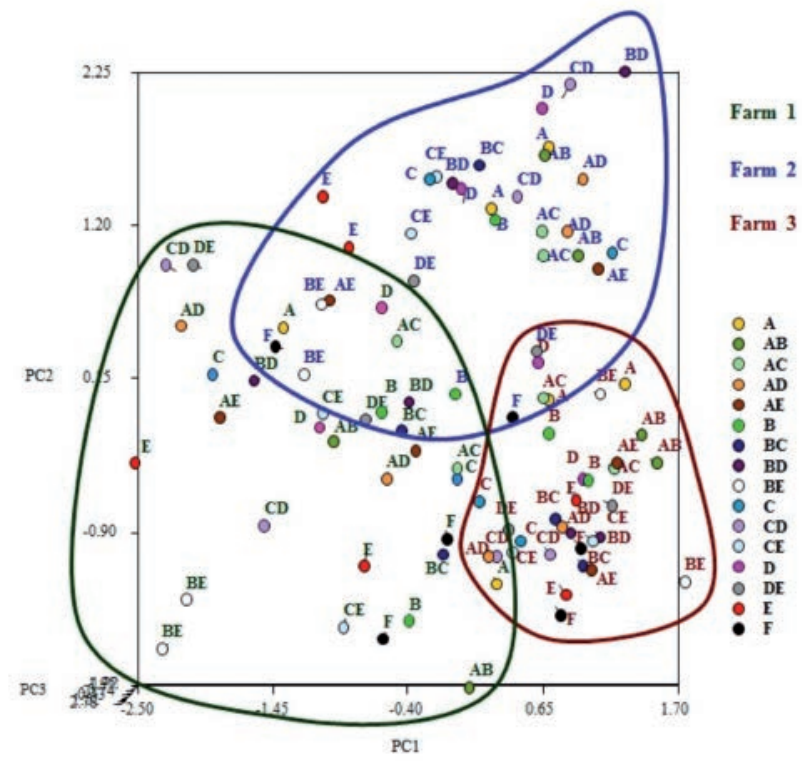

Figure 4. Two-dimensional representation of the available varietal combinations (theses) highlighting the distribution by farm. 
higher $\mathrm{W}$ values with a more balanced $\mathrm{P} / \mathrm{L}$ ratio. Low $\mathrm{W}$ values necessitate that bread be prepared with artisan methods (sourdough) to produce bread with appreciable sensory qualities (results not published). Notwithstanding the low $\mathrm{W}$ values, palatable bread made with Verna was shown to have superior functional properties, as shown from a reduced risk of potential cardiovascular problems in a healthy population (Sofi et al., 2010).

The mineral content measured on whole-wheat flour was similar to that reported previously (Ficco et al., 2009; Zhao et al., 2009; Hernández Rodríguez et al., 2011). The content of some minerals (Ca, K, Zn) was on average higher in the ancient varieties. Moreover, ARP tended to be slightly higher, in absolute terms, in some ancient varieties or mixtures of them respect to the modern variety, even though this was not significantly different from Palesio. However, as reported by $\mathrm{Di}$ Silvestro et al. (2012), Verna showed the highest secondary metabolite content and ARP.

Secondary metabolite content and ARP were strongly influenced by environment and from the interaction Farm $\times$ Variety, as has been shown by other researchers (Heimler et al., 2010; Lv et al., 2013; Lu et al., 2015). Protein content was also significantly and positively associated with $\mathrm{Ca}, \mathrm{Mn}, \mathrm{Zn}$ and P. For the $\mathrm{Zn}$ element, our results were in accord with those of other authors (Feil and Fossati, 1995; Morgounov et al., 2007); similar results for P element were reported by Tang et al. (2008).

As far as the secondary metabolite contents and antiradical power are concerned, ARP tended to be slightly higher in the ancient varieties, even though this was not significantly different from Palesio. As reported by Di Silvestro et al. (2012), Verna cultivated singularly showed the highest secondary metabolite content and ARP. Hence, the mixtures in which Verna is present had higher values of functional parameters than those of remaining varieties cultivated singularly.

Results from the present study also indicate the influence of environment (farm) on various parameters. From the PCA, Farm 2 and 3 formed distinguishable clusters, showing that all the commercial and rheological parameters were significantly influenced by environment. The low total protein, dry gluten, W, P and L values on Farm 1 were attributable to the lower degree of soil fertility. Farm 3 showed superior dough tenacity, whereas Farm 2 a higher dough strength, respectively.

\section{Conclusions}

In conclusion, the present study (PCA analysis) shows that for the ancient Tuscan Triticum aestivum L. varieties, cultivated either singularly or in mixture, the environment has a greater influence on the expression of the parameters measured than the genotype. As far as the genotype is concerned, Verna and Gentil rosso show the best ARP and rheological properties, which are extended to their respective combination mixtures. The most interesting effect, from a nutritional and functional point of view, is the relationship between ARP (polyphenol content), rheological properties, protein content and gluten content. These characteristics could provide the basis for selecting both ancient varieties as well as bread-making processes suitable for artisanal bakeries to produce a functional bread capable of protecting people from the increasing incidence of chronic diseases, without resorting to external additives, which are increasingly being used in food industry.

Our study highlights also the potential of ancient wheat germplasm in future breeding programs. In order to obtain varieties with a balanced ratio between technological and functional properties (with potential positive effects on health), it is essential to maintain on the one hand an acceptable $W$ value and gluten strength, typical of modern varieties, and on the other hand keep the high content of beneficial secondary metabolites found in some ancient varieties.

\section{References}

Adom KK, Liu RH, 2002. Antioxidant activity of grains. J. Agric. Food Chem. 50:6182-7.

Adom KK, Sorrells ME, Liu RH, 2003. Phytochemical profiles and antioxidant activity of wheat varieties. J. Agric. Food Chem. 51:7825-34.

Benedettelli S, Ghiselli L, Martinelli T, 2013. Pane nuovo e pane antico: evoluzione delle varietà di grano, della tecnica molitoria e panificatoria. In Pane Nuovo Da Grani Antichi. Industrie Grafiche Pacini Editore, Pisa, Italy, pp 25-77.

Bordes J, Branlard G, Oury FX, Charmet G, Balfourier F, 2008. Agronomic characteristics, grain quality and flour rheology of 372 bread wheats in a worldwide core collection. J. Cereal Sci. 48:569-79.

Brand-Williams W, Cuvelier ME, Berset CLWT, 1995. Use of a free radical method to evaluate antioxidant activity. LWT-Food Sci. Technol. 28:25-30.

Di Silvestro R, Marotti I, Bosi S, Bregola V, Segura Carretero A, Sedej I, Mandic A, Sakac M, Benedettelli S, Dinelli G, 2012. Health-promoting phytochemicals of Italian common wheat varieties grown under low-input agricultural management. J. Sci. Food Agric. 92:2800-10.

Dinelli G, Marotti I, Bosi S, Benedettelli S, Ghiselli L, CortaceroRamírez S, Carrasco-Pancorbo A, Segura-Carretero A, FernándezGutiérrez A, 2007. Lignan profile in seeds of modern and old Italian soft wheat (Triticum aestivum L.) cultivars as revealed by CE-MS analyses. Electrophoresis 28:4212-9.

Dinelli G, Segura-Carretero A, Di Silvestro R, Marotti I, Arráez-Román D, Benedettelli S, Ghiselli L, Fernández-Gutiérrez A, 2011. Profiles of phenolic compounds in modern and old common wheat varieties determined by liquid chromatography coupled with time-of-flight mass spectrometry. J. Chromatogr. A 1218:7670-81.

Failla 0, Funi G, 2006. Gli agronomi in Lombardia: dalle cattedre ambulanti ad oggi. Franco Angeli, Milano, Italy.

Feil B, Fossati D, 1995. Mineral composition of triticale grains as related to grain yield and grain protein. Crop Sci. 35:1426-31.

Ficco DBM, Riefolo C, Nicastro G, De Simone V, Di Gesù AM, Beleggia R, Platani C, Cattivelli L, De Vita P, 2009. Phytate and mineral elements concentration in a collection of Italian durum wheat cultivars. Field Crops Res. 111:235-42.

Finckh MR, Gacek ES, Goyeau H, Lannou C, Merz U, Mundt CC, Munk L, Nadziak J, Newton AC, de Vallavieille-Pope C, Wolfe MS, 2000. Cereal variety and species mixtures in practice. Agronomie 20:813-37.

Garrett KA, Mundt CC, 1999. Epidemiology in mixed host populations. Phytopathology 89:984-90.

Gasztonyi MN, Farkas RT, Berki M, Petróczi IM, Daood HG, 2011. Content of phenolics in wheat as affected by varietal and agricultural factors. J. Food Compos. Analysis 24:785-9.

Ghiselli L, Benedettelli S, Neri L, 2010. Varietà di frumento antiche potenziali fonti di qualità. Suppl. Inf. Agr. 38:1-3.

Ghiselli L, Sofi F, Whittaker A, Gori AM, Casini A, Abbate R, Gensini GF, Dinelli G, Marotti I, Benedettelli S, 2013. Effect of pasta consumption obtained by an old Italian durum wheat variety on cardiovascular parameters: an intervention study. Progr. Nutr. 15:265-73.

Ghiselli L, Tallarico R., Romagnoli S, De Acutis L, Benedettelli S, 2015. Antioxidant and mineral element characterisation in spontaneous hop (Humulus lupulus L.) in central Italy. Agrochimica 59:319-34.

Guarda G, Padovan S, Delogu G, 2004. Grain yield, nitrogen-use efficiency and baking quality of old and modern Italian bread-wheat cultivars grown at different nitrogen levels. Eur. J. Agron. 21:181-92.

Heimler D, Vignolini P, Isolani L, Arfaioli P, Ghiselli L, Romani A, 2010. Polyphenol content of modern and old varieties of Triticum aes- 
tivum L. and T. durum Desf. grains in two years of production. J. Agric. Food Chem. 58:7329-34.

Hernández Rodríguez L, Alfonso Morales D, Rodríguez Rodríguez E, Díaz Romero C, 2011. Minerals and trace elements in a collection of wheat landraces from the Canary Islands. J. Food Compos. Analysis 24:1081-90.

ISO (International Standardisation Organisation), 2008. ISO 27971:2008 Cereals and cereal products - Common wheat (Triticum aestivum L.) - Determination of alveograph properties of dough at constant hydration from commercial or test flours and test milling methodology. Available from: http//www.iso.org/iso/ home/store/catalogue_ics/catalogue_detail_ics.htm?csnumber=44449

Italian Regulation, 1994. Decreto Ministeriale 23 luglio 1994. Approvazione dei "Metodi ufficiali di analisi dei cereali e derivati Supplemento n. 4". In: G.U. Ser. Gen. n. 186, 10/8/1994 - Suppl. Ord. n. 114, available from: http://www.gazzettaufficiale.it/eli/id/ 1994/08/10/094A4960/sg

Leoncini E, Prata C, Malaguti M, Marotti I, Segura-Carretero A, Catizone P, Dinelli G, Hrelia S, 2012. Phytochemical profile and nutraceutical value of old and modern common wheat cultivars. Plos One 7:1-13.

Lu Y, Lv J, Hao J, Niu Y, Whent M, Costa J, Yu L, 2015. Genotype, environment, and their interactions on the phytochemical compositions and radical scavenging properties of soft winter wheat bran. Food Sci. Technol. 60:277-83.

Lv J, Lu Y, Niu Y, Whent M, Ramadan MF, Costa J, Yu L, 2013. Effect of genotype, environment, and their interaction on phytochemical compositions and antioxidant properties of soft winter wheat flour. Food Chem. 138:454-62.

Mazzoncini M, Antichi D, Silvestri N, Ciantelli G, Sgherri C, 2015. Organically vs conventionally grown winter wheat: Effects on grain yield, technological quality, and on phenolic composition and antioxidant properties of bran and refined flour. Food Chem. 175:445-51.

Morgounov A, Gomez-Becerra HF, Abugalieva A, Dzhunusova M, Yessimbekova M, Muminjanov H, Zelenskiy Y, Ozturk L, Cakmak I, 2007. Iron and zinc grain density in common wheat grown in Central Asia. Euphytica, 155: 193-203.
Mpofu A, Sapirstein HD, Beta T, 2006. Genotype and environmental variation in phenolic content, phenolic acid composition, and antioxidant activity of hard spring wheat. J. Agric. Food Chem. 54:1265-70.

Mundt CC, 2002. Performance of wheat cultivars and cultivar mixtures in the presence of Cephalosporium stripe. Crop Prot. 21:93-9.

Okarter N, Liu CS, Sorrells ME, Liu R H, 2010. Phytochemical content and antioxidant activity of six diverse varieties of whole wheat. Food Chem. 119:249-57.

Singleton VL, Orthofer R, Lamuela-Raventos RM, 1999. Analysis of total phenols and other oxidation substrates and antioxidants by means of Folin-Ciocalteu reagent. Meth. Enzymol. 299:152-78.

Sofi F, Ghiselli L, Cesari F, Gori AM, Mannini L, Casini A, Vazzana C, Vecchio V, Gensini GF, Abbate R, Benedettelli S, 2010. Effects of short-term consumption of bread obtained by an old Italian grain variety on lipid, inflammatory and haemorheological variables: an intervention study. J. Medicin. Food 13:1-6.

Stracke B A, Eitel J, Watzl B, Mäder P, Rüfer C E, 2009. Influence of the production method on phytochemical concentrations in whole wheat (Triticum aestivum L.): a comparative study. J. Agric. Food Chem. 57:10116-21.

Swanston JS, Newtona AC, Brosnanb JM, Fotheringhamb A, Glasgow E, 2005 . Determining the spirit yield of wheat varieties and variety mixtures. J. Cereal Sci. 42:127-34.

Tang J, Zou C, He Z, Shi R, Ortiz-Monasterio I, Qu Y, Zhang Y, 2008. Mineral element distributions in milling fractions of Chinese wheats. Journal of Cereal Sciences 48: 821-828.

Van den Broeck HC, de Jong HC, Salentijn EMJ, Dekking L, Bosch D, Hamer RJ, Gilissen LJ WJ, van der Meer IM, Smulders MJM, 2010. Presence of celiac disease epitopes in modern and old hexaploid wheat varieties: wheat breeding may have contributed to increased prevalence of celiac disease. Theor. Appl. Genet. 121:1527-39.

William RM, 0'Brien L, Eagles HA, Solah VA, Jayasena V, 2008. The influences of genotype, environment, and genotype $\mathrm{x}$ environment interaction on wheat quality. Austr. J. Agric. Res. 59:95-111.

Zhao FJ, Su YH, Dunhama SJ, Rakszegi M, Bedo Z, McGrath SP, Shewry $\mathrm{PR}, 2009$. Variation in mineral micronutrient concentrations in grain of wheat lines of diverse origin. J. Cereal Sci. 49:290-5. 